\title{
Understanding the impact of moderate-intensity pulsed electric fields (MIPEF) on structural and functional characteristics of pea, rice and gluten concentrates
}

\author{
Sofia Melchior $^{1} \cdot$ Sonia Calligaris $^{1}\left(\mathbb{D} \cdot\right.$ Giulia Bisson $^{1} \cdot$ Lara Manzocco $^{1}$ \\ Received: 21 July 2020 / Accepted: 30 October 2020 / Published online: 10 November 2020 \\ (C) The Author(s) 2020
}

\begin{abstract}
Aim The effect of moderate-intensity pulsed electric fields (MIPEF) was evaluated on vegetable protein concentrates from pea, rice, and gluten.

Methods Five percent (w/w) suspensions of protein concentrates ( $\mathrm{pH} 5$ and 6) were exposed to up to 60,000 MIPEF pulses at $1.65 \mathrm{kV} / \mathrm{cm}$. Both structural modifications (absorbance at $280 \mathrm{~nm}$, free sulfhydryl groups, FT-IR-spectra) and functional properties (solubility, water and oil holding capacity, foamability) were analyzed.

Results MIPEF was able to modify protein structure by inducing unfolding, intramolecular rearrangement, and formation of aggregates. However, these effects were strongly dependent on protein nature and $\mathrm{pH}$. In the case of rice and pea samples, structural changes were associated with negligible modifications in functional properties. By contrast, noticeable changes in these properties were observed for gluten samples, especially after exposure to 20,000 pulses. In particular, at $\mathrm{pH} 6$, an increase in water and oil holding capacity of gluten was detected, while at $\mathrm{pH} 5$, its solubility almost doubled.

Conclusion These results suggest the potential of MIPEF to steer structure of proteins and enhance their technological functionality.
\end{abstract}

Keywords PEF $\cdot$ Vegetable proteins $\cdot \mathrm{pH} \cdot$ Functionality $\cdot$ Water solubility

\section{Introduction}

The increasing issues associated with sustainability and food security of proteins consumption have led to an increase interest in the utilization of plant proteins (Boland et al. 2013; FAO 2013, 2017). The latter has lower production costs and are less resource intensive, and more environmental friendly than animal ones (Fasolin et al. 2019; van der Spiegel et al. 2013). From a nutritional point of view, it is widely accepted that a partial replacement of animal proteins with vegetable ones is associated with the reduction of health diseases such as type 2 diabetes and cardiovascular disease (Song et al. 2016; Tharrey et al. 2018). However, it is a matter of fact that the valuable protein fraction of many plant sources is currently

Sonia Calligaris

sonia.calligaris@uniud.it

1 Dipartimento di Scienze Agroalimentari, Ambientali e Animali, Università di Udine, via Sondrio 2/A, 33100 Udine, Italy underutilized or lost as waste (Papargyropoulou et al. 2014). This is due to the fact that plant proteins are strongly entrapped within the fibre cell walls and into the intracellular matrix of cotyledons (Preece et al. 2017). For this reason, it is necessary to find out effective technologies able to disrupt plant cellular integrity and assist protein extraction. To this aim, the application of different unconventional technologies, such as ultrasonication, high pressure homogenization and pulsed electric fields, has been recently proposed (Grimi et al. 2014; Pojić et al. 2018; Ran et al. 2019; Zhang et al. 2017). On the other hand, the application of these technologies is also claimed to modify the structure of food biopolymers (Knorr et al. 2011) Considering proteins, the intense energy inputs delivered during the application of these technologies lead to structural modifications (i.e. primary, secondary or tertiary structure) that finally affect protein technological functionalities (e.g. solubility as well as water holding, emulsifying, gelling, foaming capacity) (Esteghlal et al. 2019). The last frontier of the possible application of these technologies is their exploitation as tool to steer protein functionalities. This novel application is particularly interesting in the case of plant 
proteins, which have lower technological functionalities in comparison with animal ones. The process-induced modification of the technological performance of plant proteins is currently regarded as a key strategy to substantially increase their usage in food formulations.

Among unconventional technologies, pulsed electric fields is a non-thermal technology considered a green extractionassisting process compared with the traditional ones due to higher extraction yield, lower energy consumption and reduced utilization of solvents. PEF technology is based on the application of short pulses ( $\mu \mathrm{s}-\mathrm{ms}$ ) of high voltage electric field to a food material placed between a set pair of electrodes. Based on the electric field applied, PEF treatment can be conducted in high $(15-80 \mathrm{kV} / \mathrm{cm})$ (HIPEF) or moderate-intensity $(<5 \mathrm{kV} / \mathrm{cm})$ (MIPEF) conditions (Soliva-Fortuny et al. 2009; Timmermans et al. 2019; Toepfl et al. 2006). The major concerns for implementation of PEF technology in the food sector are the investment cost and the development of industrial equipment (Puértolas et al. 2012). However, compared to HIPEF, moderate-intensity pulsed electric fields (MIPEF) are less energy intensive and much more cost affordable (Soliva-Fortuny et al. 2009; Timmermans et al. 2019; Toepfl et al. 2006). It has been estimated that the cost of a generator with an average load power of $30 \mathrm{~kW}$ and a voltage of $30 \mathrm{kV}$ is $100-200 \mathrm{k} €$ which is lower than the cost of the high-intensity equipment. Moreover, it is expected that the short processing time as well as the low energy consumption might amortize this investment within a very short period of time (Picart-Palmade et al. 2019; Puértolas et al. 2012).

Both PEF technologies has been demonstrated to efficiently disrupt plant cell by inducing the electroporation of membranes and thus favouring the extractability of valuable compounds, such as proteins, from plant materials (Barba et al. 2015; Donsì et al. 2010; Pataro et al. 2017; Puértolas et al. 2012; Soliva-Fortuny et al. 2009; Yu et al. 2015; Zhang et al. 2017). It should be highlighted that the PEF impact on protein structure during both protein-assisted extraction and treatments aimed to protein-structure modifications has been studied for HIPEF treatments solely (Giteru et al. 2018, 2020). In particular, HIPEF could develop dipole moments causing ionization of the amino and carboxylic groups. The charged dipoles induce the development of electrostatic attractions which are responsible for unfolding, aggregation and crosslinking phenomena (Dong et al. 2020; Giteru et al. 2018, 2020; Liu et al. 2011; Xiang et al. 2011a). These events can lead finally to a decrease in the ordered structures ( $\alpha$-helices), an increase in disorder ones ( $\beta$-sheets, $\beta$-turns and random coils) and a higher exposure of surface free sulfhydryls $(\mathrm{S}-\mathrm{H})$ (Guan et al. 2010; Liu et al. 2013). As summarized by Giteru et al. (2020), all these modifications generate the formation of transient structures and changes in the interfacial properties of the proteins, which influence their functional properties including surface hydrophobicity ( $\mathrm{Li}$ et al. 2007; Wu et al. 2016), colloidal behaviour (Xiang et al. 2011b), thermal stability (Liu et al. 2011) and swelling index (Li et al. 2007). To this regard, it is noteworthy that structural modification of enzymes, such as papain, POD, PPO, lysozyme and LOX, exposed to PEF was found to be responsible for their irreversible inactivation (Luo et al. 2010; Yeom et al. 1999; Zhao and Yang 2008, 2010; Zhong et al. 2007).

On the other hand, the effects of MIPEF on protein structure and relevant technological functionality have received little attention in literature. However, it is a matter of fact that fundamental knowledge on the effect of MIPEF on structural and technological properties of proteins, and especially plant proteins, is highly demanded to propose this technology for food applications. To this aim, in this research, aqueous suspensions $(5 \% \mathrm{w} / \mathrm{w})$ of commercial vegetable protein concentrates of pea, rice and wheat gluten protein concentrates were subjected to MIPEF treatments at $1.65 \mathrm{kV} / \mathrm{cm}$ for increasing number of pulses $(0,20,000$ and 60,000$)$. This concentration was chosen in the protein content range of the different plant matrices here considered (Aluko et al. 2009; Cao et al. 2009; Shand et al. 2007) as well as to better study MIPEF effects (Barsotti et al. 2001). It should be noted that pea proteins were chosen for their promising functional properties and low cost (Aluko et al. 2009; Boye et al. 2010; Osen et al. 2014; Shand et al. 2007); rice proteins were selected for being colourless and tasteless (Cao et al. 2009; Wang et al. 2016); and gluten was chosen for its unique rheological properties (Day et al. 2006). Treated samples were then evaluated for both structural modifications (absorbance at $280 \mathrm{~nm}$, free sulfhydryl groups, FT-IR-spectra) and functional properties (solubility, water and oil holding capacity, foam ability).

\section{Materials and Methods}

\section{Materials}

Wheat gluten concentrate (protein content $75 \% \mathrm{w} / \mathrm{w}$ ) from Sigma-Aldrich (St. Louis, Missouri, USA) and concentrates of pea and rice (protein content $80 \% \mathrm{w} / \mathrm{w}$ ) from Raab Vitalfood GmbH (Rohrbach, Germany) were used. Tris base, SDS, glycine, ethylenediaminetetraacetic acid (EDTA), phosphate monosodium $\left(\mathrm{NaH}_{2} \mathrm{PO}_{4}\right)$, disodium phosphate $\left(\mathrm{Na}_{2} \mathrm{HPO}_{4}\right)$, sodium dodecyl sulphate (SDS), $\beta$ mercaptoethanol, 5,5'-dithiobis-(2-nitrobenzoic acid) (DTNB) and acetic acid were provided by Sigma-Aldrich (Milan, Italy). Mini-PROTEAN@ TGX Stain-Free ${ }^{\mathrm{TM}}$ Precast Gels (4568083), Laemmli Sample Buffer 2x (161-0737), Bio-Safe ${ }^{\mathrm{TM}}$ Coomassie G-250 Stain (161-0786) and Precision Plus Protein $^{\mathrm{TM}}$ Kaleidoscope ${ }^{\mathrm{TM}}$ Standards (161-0375) molecular weight marker were purchased from Bio-Rad (Hercules, CA, USA). Hydrochloric acid and methanol were provided by Carlo Erba (Milan, Italy). Dimethylformamide was purchased from Jassen (Geel, Belgium) and sunflower oil was bought from a 
local market. Deionized water (System advantage A10®, Millipore S.A.S, Molsheim, France) was used.

\section{Sample Preparation and PEF Treatment}

Pea, rice or gluten concentrate suspensions $(5 \% \mathrm{w} / \mathrm{w})$ were prepared by adding phosphate buffer $(0.005 \mathrm{M})$ at $\mathrm{pH} 5$ or 6. This concentration was used to facilitate PEF treatments, since low concentration protein solutions exhibit high electrical resistance, such that greater pulse widths are necessary for studying the structural modifications of food protein (Barsotti et al. 2001).

Samples $(15 \mathrm{~mL})$ were solubilized overnight at $25^{\circ} \mathrm{C}$ and processed at a constant electric field strength $(\mathrm{E}=1.65 \mathrm{kV} /$ $\mathrm{cm}$ ) generated by a M100 ScandiNova generator (Uppsala, Sweden) able to deliver square pulses to the parallelepiped treatment chamber (16.8-mL volume capacity), with a 1.5$\mathrm{cm}$ gap between the two stainless electrodes. The pulse width $(5 \mu \mathrm{s})$ and frequency $(400 \mathrm{~Hz})$ were kept constant while the number of pulses was set at 20,000 or 60,000 . Processing parameters were controlled by LabVIEW4PEF software (LabVIEW4PEF_B-618-01 9.0, ProdAl, Fisciano, Italy). As reference sample, untreated protein concentrate suspension at $\mathrm{pH} 5$ or 6 was used. After the treatment, the suspensions were freeze-dried (Laboratory and Pilot Freeze-Dryer Mini-Fast Edwards, mod. 1700, Edwards Alto Vuoto, Milan, Italy) and stored in desiccators before further analysis.

\section{Structure Characterization}

\section{SDS PAGE}

Protein profiles were analyzed by SDS PAGE according to Laemmli (1970). A known amount of sample was mixed with $500-\mu \mathrm{L}$ Laemmli sample buffer and $2 \%$ of $\beta$ mercaptoethanol. The mixtures were incubated at room temperature for $1 \mathrm{~h}$, and then heated at $100^{\circ} \mathrm{C}$ for $5 \mathrm{~min}$ in a water bath equipped with a magnetic stirrer (C-MAG HS 7, IKA®Werke GmbH \& Co. KG, Staufen, Germany). Ten microliters of samples were loaded onto polyacrylamide gels in order to have in each well the same protein content $(50 \mu \mathrm{g})$. Running buffer was made of $1.92 \mathrm{M}$ glycine, 250-mM Tris and $1 \%$ SDS. A molecular weight (MW) standard consisting of a cocktail of ten proteins with known MWs $(250,150,100$, $75,50,37,25,20,15$ and $10 \mathrm{kDa}$ ) was used to indicate the MW range of sample. Runs were performed on a MiniPROTEAN® Tetra Cell apparatus (Bio-Rad, Hercules, CA, USA) at constant amperage of $30 \mathrm{~mA}$; the run was stopped when the samples reached the bottom of the gel. Subsequently, gels were placed for $30 \mathrm{~min}$ in a gel-fixing solution (40\% methanol and $10 \%$ acetic acid) and stained with Coomassie blue overnight. Gels were destained with water for
30 min and images were obtained with gel documentation system G:BOX (Chemi XX9, Syngene, Cambridge, UK).

\section{FT-IR}

FT-IR spectra were recorded at $25 \pm 1{ }^{\circ} \mathrm{C}$ by using a FT-IR instrument, equipped with an ATR accessory and a Zn-Se crystal that allow collection of FT-IR spectra directly on sample without any special preparation (Alpha-P, Bruker Optics, Milan, Italy). The "pressure arm" of the instrument was used to apply constant pressure to the sample, positioned onto the $\mathrm{Zn}-\mathrm{Se}$ crystal, to ensure a good contact between the sample and the incident IR beam. All FT-IR spectra were collected in the range from 4000 to $400 \mathrm{~cm}^{-1}$, at a spectrum resolution of 4 $\mathrm{cm}^{-1}$ and with 32 coadded scans. Background scan of the clean $\mathrm{Zn}-\mathrm{Se}$ crystal was acquired prior to sample scanning. The collected FT-IR spectra were pre-processed (baseline corrected, smoothened and normalized) using the OPUS software (version 7.0 for Microsoft Windows, Bruker Optics, Milan, Italy) and Gaussian curve fitting of deconvoluted amide I (1600-1700 $\mathrm{cm}^{-1}$ ) was performed using Origin Pro 9 (OriginLab, Northampton, MA, USA) accordingly with Sow and Yang (2015) and Sow et al. (2017). The fitting quality of the Gaussian curves was confirmed by having $R^{2}>0.997$.

\section{Absorbance at $280 \mathrm{~nm}$}

The absorption spectroscopy measurements at $280 \mathrm{~nm}$ were performed by a UV-Vis spectrophotometer (UV-2501 PC, Shimadzu Kyoto, Japan) at $25{ }^{\circ} \mathrm{C}$ with a $1-\mathrm{cm}$ path-length cuvette. Samples were diluted with $0.5 \%$ (w/v) SDS-0.05 M sodium phosphate buffer solution ( $\mathrm{pH}$ 6.9) to obtain absorbance signals on scale.

\section{Free Sulfhydryl Content}

The concentration of free sulfhydryl groups ( $\mathrm{SH}$ ) was determined using Ellman's reagent (DTNB) according to the method of Panozzo et al. (2014).

\section{$\zeta$-Potential}

Electrical charge of the treated samples was measured after 1:1000 dilutions at $25{ }^{\circ} \mathrm{C}$ using the dynamic light scattering (DLS) system (NanoSizer 3000, Malvern Instruments, Malvern, UK).

\section{Functional Properties Determination}

\section{Solubility}

Water dispersions containing $1 \%(\mathrm{w} / \mathrm{w})$ sample were stirred at room temperature for $1 \mathrm{~h}$ and then centrifuged (Mikro 120, 
Hettich Italia srl, Milan, Italy) at $13,500 \times g$ for $5 \mathrm{~min}$. The supernatant was eliminated, and the insoluble fraction was dried in a vacuum oven (Vuotomatic 50, Bicasa, Milan, Italy) overnight and exactly weighted. Sample solubility was calculated by Eq. 1 :

Protein concentrate solubility $(\%)=\frac{S-D I F}{S} \times 100$

where $S$ is the initial sample weight and DIF is the weight of the dried insoluble fraction.

\section{WHC and $\mathrm{OHC}$}

Samples (S) were dispersed into distilled water or sunflower oil $(0.2 \mathrm{~g} / \mathrm{mL}$ ), stirred using a vortex (Vortex 1, Ika, Milan, Italy) and centrifuged three times for $5 \mathrm{~min}$ at $13,900 \times \mathrm{g}$. The supernatant was eliminated, and the pellet obtained was weighted $(\mathrm{H})$. Water and oil holding capacity were calculated as the percentage of water or oil held by the sample, following Eq. 2.

WHC $(\%)$ or $O H C(\%)=\frac{H-S}{S} * 100$

\section{Foaming Properties}

Samples were suspended in water $(1 \% \mathrm{w} / \mathrm{w})$ under stirring for $60 \mathrm{~min}$ at room temperature. Aliquots of $10-\mathrm{mL}$ suspension were homogenized (Polytron DI 25 basic, IKA Werke GmbH \& Co., Germany) for $3 \mathrm{~min}$ at $800 \times g$ in a graduated cylinder and the volumes of foam and liquid phase were measured after $0,15,30$ and $60 \mathrm{~min}$. The foaming capacity (FC) and the foam stability (FS) were computed following Eq. 3:

$\mathrm{FC}(\%)=\frac{V_{t}}{V_{0}} * 100$

where $V_{t}$ is the volume of foam at time $t$ and $V_{0}$ is the initial liquid phase volume.

\section{Data Analysis}

All determinations were expressed as the mean \pm standard deviation (SD) of at least three measurements. Analysis of variance (ANOVA) was performed by using $R$ v. 3.1.1 for Windows (The $\mathrm{R}$ foundation for statistical computing). A Tukey's post hoc test was used to assess differences between means $(p<0.05)$.

\section{Results and Discussion}

\section{Effect of MIPEF Treatment on Protein Structure}

The effect of moderate-intensity pulsed electric field (MIPEF) on commercial vegetable protein concentrates (pea, rice, and gluten) having protein concentration higher than $75 \%$ was studied. In particular, MIPEF effects were evaluated on suspensions of proteins at $\mathrm{pH} 5$ or 6 . Treated suspensions were initially investigated for protein structure by SDS PAGE. As an example, Fig. 1 reports the electrophoretograms of gluten samples subjected to MIPEF treatments.

All the bands typically associated with HMW glutenins (80-140 kDa), $\omega$-gliadinis (60-80 kDa), LMW gliadins (30-70 kDa), $\alpha, \beta$ and $\gamma$-gliadins ( $30-50 \mathrm{kDa}$ ) and globulins and albumins $(10-15 \mathrm{kDa})$ were detected (Nadeem et al. 2016). Independently on the $\mathrm{pH}$ of the suspension, no changes were observed in the molecular size of gluten proteins, which presented the same electrophoretic mobility of the untreated sample ( 0 pulse). Analogous results were also obtained in the case of MIPEF-treated pea and rice protein concentrates (data not shown). These results seem to indicate that no aggregation nor primary structure modifications were induced by MIPEF treatments. In literature, there are contrasting results on this aspect. Some authors described the aggregation of proteins induced by HIPEF treatments (Wu et al. 2016; Zhang et al. 2017). These results differ from those of Qian et al. (2016) that found no aggregation upon PEF treatments of egg with proteins. These discrepancies could be due to the different type of proteins considered as well as treatment conditions applied. In our case, the reduced energy involved in MIPEF was not able to affect protein primary structure but could have been sufficient to exert conformational changes (Barsotti et al. 2001; Ohshima et al. 2007; Qian et al. 2016). To evaluate the effects of MIPEF on the secondary structure of proteins, FT-IR spectra of the differently treated samples were performed (data not

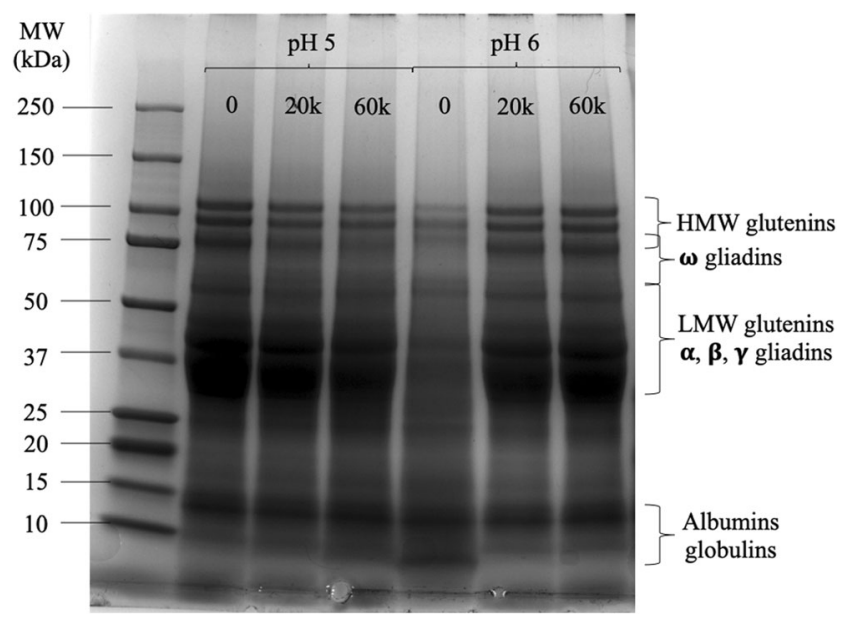

Fig. 1 SDS PAGE patterns of gluten concentrate with different $\mathrm{pH}$ treated by MIPEF at $0,20,000(20 \mathrm{k})$ and 60,000 (60 k) pulses 
shown). Between 1500 and $1700 \mathrm{~cm}^{-1}$, all samples exhibited the typical peaks of amide I and amide II, due to $\mathrm{C}=\mathrm{O}$ and $\mathrm{N}-$ $\mathrm{H}$ stretching, and bending of the peptide bonds, respectively (Ami et al. 2013). By analyzing the amide I region (1600$1700 \mathrm{~cm}^{-1}$ ), marked modifications of protein conformation were detected as a function of protein type and suspension $\mathrm{pH}$. Both pea and gluten concentrates at $\mathrm{pH} 5$ and 6, respectively, did not exhibit substantial changes in protein secondary structure, probably due to the $\mathrm{pH}$ vicinity to the isoelectric point. Similar results were observed in rice protein structure independently on $\mathrm{pH}$, indicating the scarce sensitivity of these proteins to electric fields (data not shown). By contrast the disruption of the $\alpha$-helix $\left(\sim 1650 \mathrm{~cm}^{-1}\right)$ was clearly observed in pea and gluten proteins at $\mathrm{pH} 6$ and 5, respectively (Fig. 2 a and $b$ ). These results indicate the intense effect of electric fields on the strong dipole moment of these protein conformations far from their isoelectric point. Similar effects have been previously reported for proteins exposed to HIPEF treatments (Liu et al. 2010). Figure 2 also shows that $\beta$-sheet $(\sim 1613-$ $1638 \mathrm{~cm}^{-1}$ and $\left.\sim 1680 \mathrm{~cm}^{-1}\right)$ and random coil $(\sim 1640-1648$ $\mathrm{cm}^{-1}$ ) structures noticeably changed (Carbonaro et al. 2008,
2012; Georget and Belton 2006; Shevkani et al. 2015). As well-known, $\beta$-sheets are characterized by little net dipole moment with hydrogen bonds weaker than in the $\alpha$-helix. Therefore, the loss of order and consequent destabilization of the secondary structure would occur due to the switch from $\alpha$-helix to $\beta$-sheet or random coil as well as to the disruption of $\beta$-sheets (Giteru et al. 2018; Zhang et al. 2017; Zhao et al. 2012, 2014; Zhao and Yang 2010). Results shown in Fig. 2 indicate that PEF applied at moderate intensity would induce modifications of secondary structure according to mechanisms analogous to those characterizing higher intensity treatments.

The effect of the increase in the intensity of MIPEF treatments resulted strongly dependent on protein type. In fact, a marked loss of original protein conformation was observed in pea proteins exposed even to the lower number of pulses (20,000 pulses), while a further increase in pulse number did not induce additional changes (Fig. 2a). This result indicates that most modifications of energy landscape and bound charges induced by MIPEF do not progressively increase with pulse number, at least in the range here considered. By
Fig. 2 Content of secondary structures of pea (a) and gluten (b) concentrates at $\mathrm{pH} 6$ and 5, respectively. ${ }^{\mathrm{a}-\mathrm{c}}$ whiting the same structure, means indicated by different letters are significantly different $(p<0.05)$.

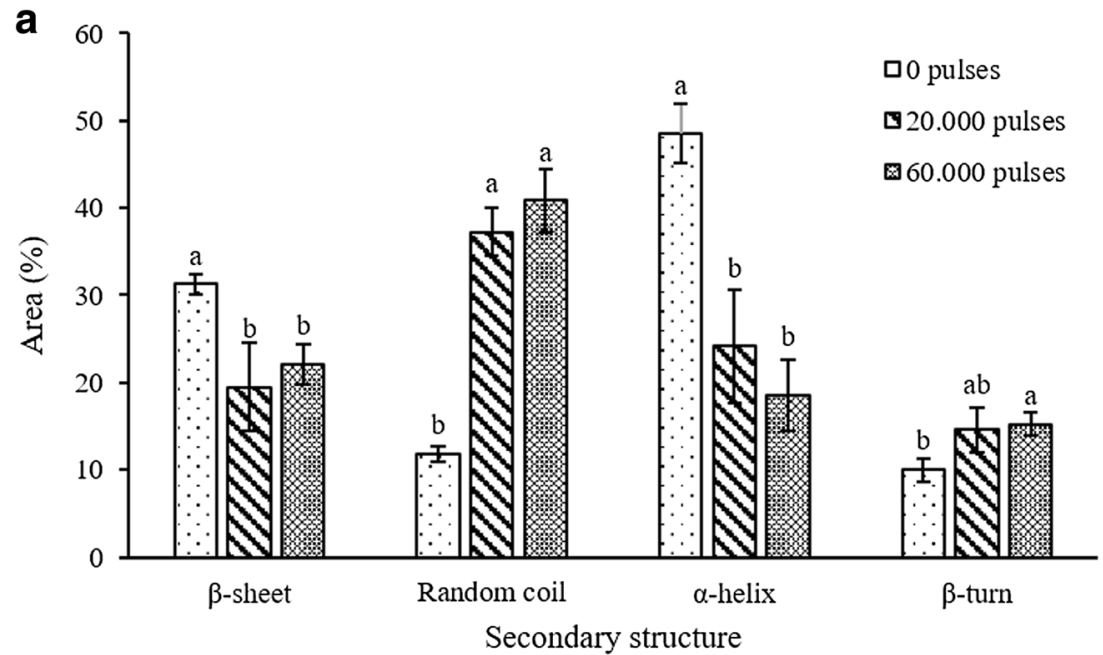

b

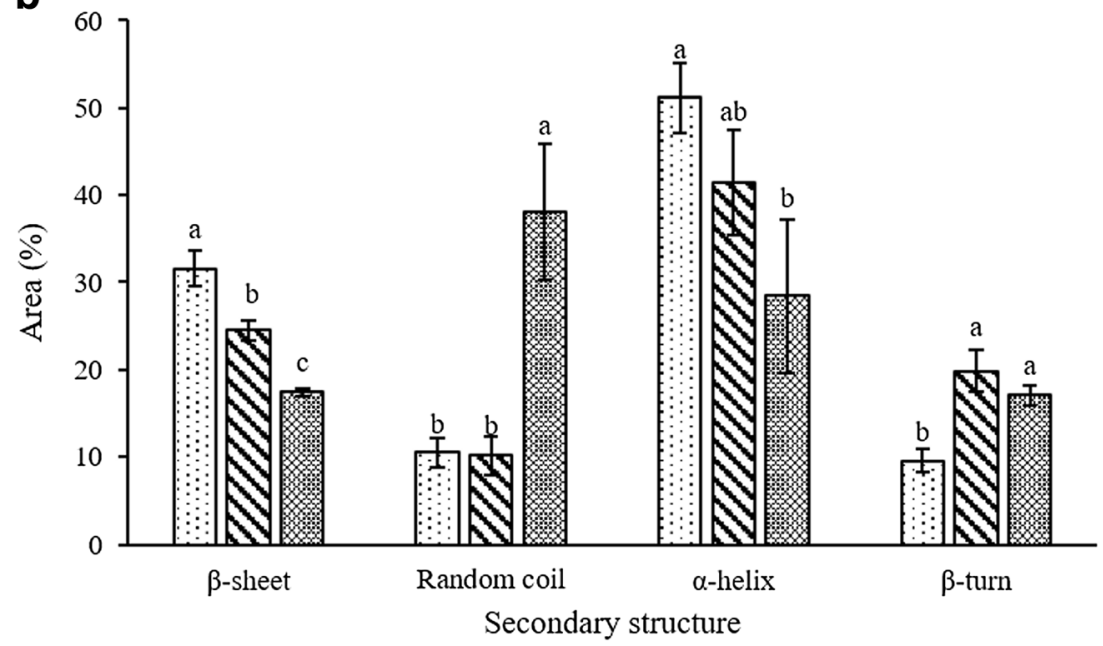


contrast, the secondary structure of gluten proteins was modified only at 60,000 pulses probably due to their complex structure (Fig. 2b).

Changes in tertiary structure induced by MIPEF treatment were investigated by measuring absorbance at $280 \mathrm{~nm}$ and free sulfhydryl content (Table 1). A decrease in absorbance is correlated to a lower exposure of tyrosine, tryptophan and cysteine, originally exposed on protein surface. Upon exposure to MIPEF, these residues would bury within protein structure (Goldfarb et al. 1951). The decrease in absorbance was observed even at the lower number of MIPEF pulses $(20,000)$. This result confirms data previously acquired by FT-IR, indicating that marked structural changes are already observed upon the application of this pulse number. In the case of pea at both $\mathrm{pH}$, the decrease in absorbance at $280 \mathrm{~nm}$ was associated with a decrease in free sulfhydryl content. A similar behaviour was also detected for gluten sample at $\mathrm{pH}$ 6. The uppermost driving force of disulphide bonding in conformational changes of proteins under electric stress has been actually reported even for HIPEF treatments (Wei et al. 2009; Zhao and Yang 2009, 2012). A decrease in free sulfhydryl groups is generally attributable to the formation of disulphide bridges at both intra- and intermolecular structural level. Covalent cross-linking would favour transient selfassembly of proteins, potentially leading to the formation of aggregates with modified surface activity and functional properties (Li et al. 2007; Liu et al. 2011; Wu et al. 2016; Xiang et al. 2011b). In gluten suspension at $\mathrm{pH}$ 6, the decrease of sulfhydryl groups was clearer as compared to the one observed in pea samples (Table 1). This is probably due to the vicinity of $\mathrm{pH}$ to the isoelectric point of gluten proteins (6.2). As a consequence, at $\mathrm{pH} 6$ gluten would present a negligible net charge, while pea proteins, having an isoelectric point equal to 4.5 , would be characterized by a prevalence of negative charges. The zeta potentials of gluten and pea proteins were actually measured by DLS and resulted $-3.71 \pm$ $0.63 \mathrm{mV}$ and $-14.13 \pm 0.90 \mathrm{mV}$, respectively. This confirms that gluten molecules would be more prone to interact by disulphide bonding due to the limited electrostatic repulsion among particles. Table 1 also shows that in gluten and rice samples at $\mathrm{pH} 5$, the decrease in absorbance occurred concomitantly with an increase in sulfhydryl groups. The latter could be due to both the exposure of internal SH groups and the disruption of disulphide bonds, potentially leading to partial protein unfolding. Such behaviour is in agreement with previous studies on soybean and egg proteins exposed to HIPEF (Fernandez-Diaz et al. 2000; Li et al. 2007).

\section{Effect of MIPEF Treatment on Technological Functionality}

To verify if the observed changes in protein conformation upon MIPEF could be associated with modifications in protein functionality, samples were further analyzed for

Table 1 Absorbance at $280 \mathrm{~nm}$ and free sulfhydryl groups of pea, rice and gluten protein concentrates at $\mathrm{pH} 5$ and 6 as a function of number of MIPEF pulses

\begin{tabular}{|c|c|c|c|c|}
\hline Protein concentrate & $\mathrm{pH}$ & Pulses & Absorbance at $280 \mathrm{~nm}$ & Sulfhydryl groups $\left(\mu \mathrm{molL} L^{-1} \mathrm{~g}^{-1}\right)$ \\
\hline \multirow[t]{6}{*}{ Pea } & \multirow[t]{3}{*}{5} & 0 & $0.552 \pm 0.010^{\mathrm{a}}$ & $1.90 \pm 0.13^{\mathrm{a}}$ \\
\hline & & 20,000 & $0.137 \pm 0.008^{\mathrm{c}}$ & $0.96 \pm 0.06^{\mathrm{b}}$ \\
\hline & & 60,000 & $0.253 \pm 0.038^{b}$ & $0.96 \pm 0.05^{\mathrm{b}}$ \\
\hline & \multirow[t]{3}{*}{6} & 0 & $0.435 \pm 0.064^{\mathrm{a}}$ & $2.03 \pm 0.08^{\mathrm{a}}$ \\
\hline & & 20,000 & $0.055 \pm 0.025^{b}$ & $1.10 \pm 0.08^{b}$ \\
\hline & & 60,000 & $0.187 \pm 0.007^{\mathrm{b}}$ & $1.03 \pm 0.01^{\mathrm{b}}$ \\
\hline \multirow[t]{6}{*}{ Rice } & \multirow[t]{3}{*}{5} & 0 & $0.602 \pm 0.016^{\mathrm{a}}$ & $0.47 \pm 0.05^{\mathrm{c}}$ \\
\hline & & 20,000 & $0.393 \pm 0.037^{\mathrm{b}}$ & $0.75 \pm 0.03^{b}$ \\
\hline & & 60,000 & $0.374 \pm 0.018^{b}$ & $1.03 \pm 0.01^{\mathrm{a}}$ \\
\hline & \multirow[t]{3}{*}{6} & 0 & $0.460 \pm 0.009^{\mathrm{a}}$ & $0.48 \pm 0.04^{\mathrm{a}}$ \\
\hline & & 20,000 & $0.371 \pm 0.014^{\mathrm{b}}$ & $0.56 \pm 0.04^{\mathrm{a}}$ \\
\hline & & 60,000 & $0.343 \pm 0.006^{\mathrm{c}}$ & $0.41 \pm 0.05^{\mathrm{a}}$ \\
\hline \multirow[t]{6}{*}{ Gluten } & \multirow[t]{3}{*}{5} & 0 & $0.618 \pm 0.086^{\mathrm{a}}$ & $1.07 \pm 0.05^{\mathrm{c}}$ \\
\hline & & 20,000 & $0.485 \pm 0.057^{\mathrm{ab}}$ & $2.39 \pm 0.12^{b}$ \\
\hline & & 60,000 & $0.367 \pm 0.003^{b}$ & $4.33 \pm 0.47^{\mathrm{a}}$ \\
\hline & \multirow[t]{3}{*}{6} & 0 & $0.872 \pm 0.025^{\mathrm{a}}$ & $3.28 \pm 0.10^{\mathrm{a}}$ \\
\hline & & 20,000 & $0.154 \pm 0.026^{\mathrm{b}}$ & $1.44 \pm 0.06^{\mathrm{c}}$ \\
\hline & & 60,000 & $0.127 \pm 0.002^{b}$ & $1.88 \pm 0.08^{b}$ \\
\hline
\end{tabular}

${ }^{\mathrm{a}-\mathrm{c}}$ For each protein concentrate, $\mathrm{pH}$, and measured property, means indicated by different letters are significantly different $(p<0.05)$ 
solubility, capacity of holding water or oil and ability to generate foams. The effect of MIPEF on samples exposed to increasing number of MIPEF pulses is shown in Table 2, with reference to solubility, WHC and OHC.

Solubility of untreated protein concentrates was in agreement with the typical range of plant proteins (around 20\% for both pea and gluten, and between 10 and 20\% for rice) (Cao et al. 2009; Lu et al. 2019; Majzoobi and Abedi 2014). When MIPEF was applied, in most cases, a significant solubility decrease was observed, regardless protein type and $\mathrm{pH}$ conditions. These results are in agreement with previous works that reported downward trend in solubility for egg white proteins after PEF treatments at $25 \mathrm{kV} / \mathrm{cm}$ up to $800 \mu \mathrm{s}$, due to the formation of insoluble protein aggregates and/or protein unfolding (Wu et al. 2014, 2016). Interestingly, gluten solubility almost doubled after 20,000 pulses at $\mathrm{pH} 5$. The application of electric fields on the protein at $\mathrm{pH}$ below its isoelectric point probably favours the exposure of protein charges, enhancing water-protein interactions and thus increasing the overall solubility.

Data relevant to WHC and $\mathrm{OHC}$ resulted particularly depending on protein type and $\mathrm{pH}$ of the suspension. As observed for solubility, in most cases, significant changes were noticed but in a narrow magnitude range, suggesting a negligible effect of the applied technology. A marked increase in both functional properties was observed only in the case of gluten at $\mathrm{pH}$ 6. As previously noted, in the vicinity of the isoelectric point, MIPEF treatments bring on the formation of aggregates stabilized by disulphide bonds (Table 1). The latter is probably able to better entrap both water and oil within the resulting network. In other words, MIPEF would modify the capacity of gluten to interact with the solvent according to mechanisms affected by $\mathrm{pH}$. In the vicinity of the isoelectric point, gluten proteins would interact with water mainly through interactions with exposed hydrophilic groups, while at lower $\mathrm{pH}$ the solvent would be also entrapped in the protein network upon interaction with buried groups. In addition, it is not excluded that the dried protein network formed at $\mathrm{pH} 6$ could physically uptake the solvents by capillarity and better hold them within the structure.

Regarding foam formation (Fig. 3), MIPEF caused a scarce effect on rice concentrate foaming (Fig. 3c and Fig. 3d). The limited effect of MIPEF on rice functional properties clearly confirms that the structural changes induced by MIPEF (Table 1) are irrelevant for the final capacity of rice proteins to interact with solvents and stabilize food structures. By contrast, MIPEF increased the foam ability in both pea (Fig. 3a and Fig. 3b) and gluten (Fig. 3e and Fig. 3f), with gluten at pH

Table 2 Solubility, water holding capacity (WHC) and oil holding capacity (OHC) of pea, rice and gluten concentrates at $\mathrm{pH} 5$ and 6 treated at 0 , 20,000 and 60,000 pulses

\begin{tabular}{|c|c|c|c|c|c|}
\hline \multirow[t]{2}{*}{ Protein concentrate } & \multirow[t]{2}{*}{$\mathrm{pH}$} & \multirow[t]{2}{*}{ Number of pulses } & \multicolumn{3}{|l|}{ Property } \\
\hline & & & Solubility (\%) & WHC (\%) & $\mathrm{OHC}(\%)$ \\
\hline \multirow[t]{6}{*}{ Pea } & \multirow[t]{3}{*}{5} & 0 & $21.1 \pm 1.2^{\mathrm{a}}$ & $264.4 \pm 3.3^{a}$ & $148.1 \pm 11.8^{\mathrm{a}}$ \\
\hline & & 20,000 & $18.0 \pm 0.6^{\mathrm{a}}$ & $259.8 \pm 1.3^{\mathrm{a}}$ & $123.4 \pm 1.9^{b}$ \\
\hline & & 60,000 & $20.0 \pm 0.1^{\mathrm{a}}$ & $244.8 \pm 1.9^{b}$ & $127.0 \pm 1.4^{\mathrm{b}}$ \\
\hline & \multirow[t]{3}{*}{6} & 0 & $23.2 \pm 0.8^{\mathrm{a}}$ & $288.4 \pm 4.6^{\mathrm{b}}$ & $124.1 \pm 2.1^{\mathrm{a}}$ \\
\hline & & 20,000 & $17.2 \pm 2.8^{b}$ & $305.1 \pm 4.2^{\mathrm{a}}$ & $151.0 \pm 15.3^{\mathrm{a}}$ \\
\hline & & 60,000 & $14.9 \pm 1.2^{b}$ & $295.5 \pm 2.1^{\mathrm{ab}}$ & $142.4 \pm 11.2^{\mathrm{a}}$ \\
\hline \multirow[t]{6}{*}{ Rice } & \multirow[t]{3}{*}{5} & 0 & $13.6 \pm 0.8^{\mathrm{a}}$ & $160.4 \pm 3.2^{b}$ & $129.7 \pm 7.7^{b}$ \\
\hline & & 20,000 & $7.6 \pm 1.7^{b}$ & $224.8 \pm 3.2^{\mathrm{a}}$ & $145.4 \pm 3.1^{\mathrm{a}}$ \\
\hline & & 60,000 & $8.4 \pm 0.6^{b}$ & $214.3 \pm 16.6^{\mathrm{a}}$ & $131.1 \pm 1.1^{\mathrm{b}}$ \\
\hline & \multirow[t]{3}{*}{6} & 0 & $16.4 \pm 0.6^{\mathrm{a}}$ & $161.3 \pm 3.9^{\mathrm{a}}$ & $146.7 \pm 9.2^{\mathrm{a}}$ \\
\hline & & 20,000 & $9.2 \pm 0.6^{b}$ & $150.2 \pm 2.1^{b}$ & $125.2 \pm 3.4^{\mathrm{b}}$ \\
\hline & & 60,000 & $10.8 \pm 0.6^{\mathrm{b}}$ & $151.0 \pm 1.5^{\mathrm{b}}$ & $136.8 \pm 1.8^{\mathrm{ab}}$ \\
\hline \multirow[t]{6}{*}{ Gluten } & \multirow[t]{3}{*}{5} & 0 & $16.2 \pm 1.5^{\mathrm{c}}$ & $84.3 \pm 6.6^{\mathrm{a}}$ & $199.3 \pm 5.7^{\mathrm{a}}$ \\
\hline & & 20,000 & $30.1 \pm 1.6^{\mathrm{a}}$ & $99.5 \pm 9.2^{\mathrm{a}}$ & $194.9 \pm 3.6^{\mathrm{a}}$ \\
\hline & & 60,000 & $27.4 \pm 0.8^{b}$ & $93.3 \pm 2.8^{\mathrm{a}}$ & $188.6 \pm 9.2^{\mathrm{a}}$ \\
\hline & \multirow[t]{3}{*}{6} & 0 & $25.0 \pm 0.9^{\mathrm{a}}$ & $63.3 \pm 0.1^{\mathrm{c}}$ & $175.5 \pm 6.1^{\mathrm{c}}$ \\
\hline & & 20,000 & $22.4 \pm 0.7^{b}$ & $114.7 \pm 0.2^{\mathrm{a}}$ & $201.5 \pm 2.7^{b}$ \\
\hline & & 60,000 & $16.4 \pm 0.7^{\mathrm{c}}$ & $97.8 \pm 1.6^{\mathrm{b}}$ & $238.8 \pm 9.1^{\mathrm{a}}$ \\
\hline
\end{tabular}

${ }^{\mathrm{a}-\mathrm{c}}$ In the same column and $\mathrm{pH}$ conditions, means indicated by different letters are significantly different $(p<0.05)$ 

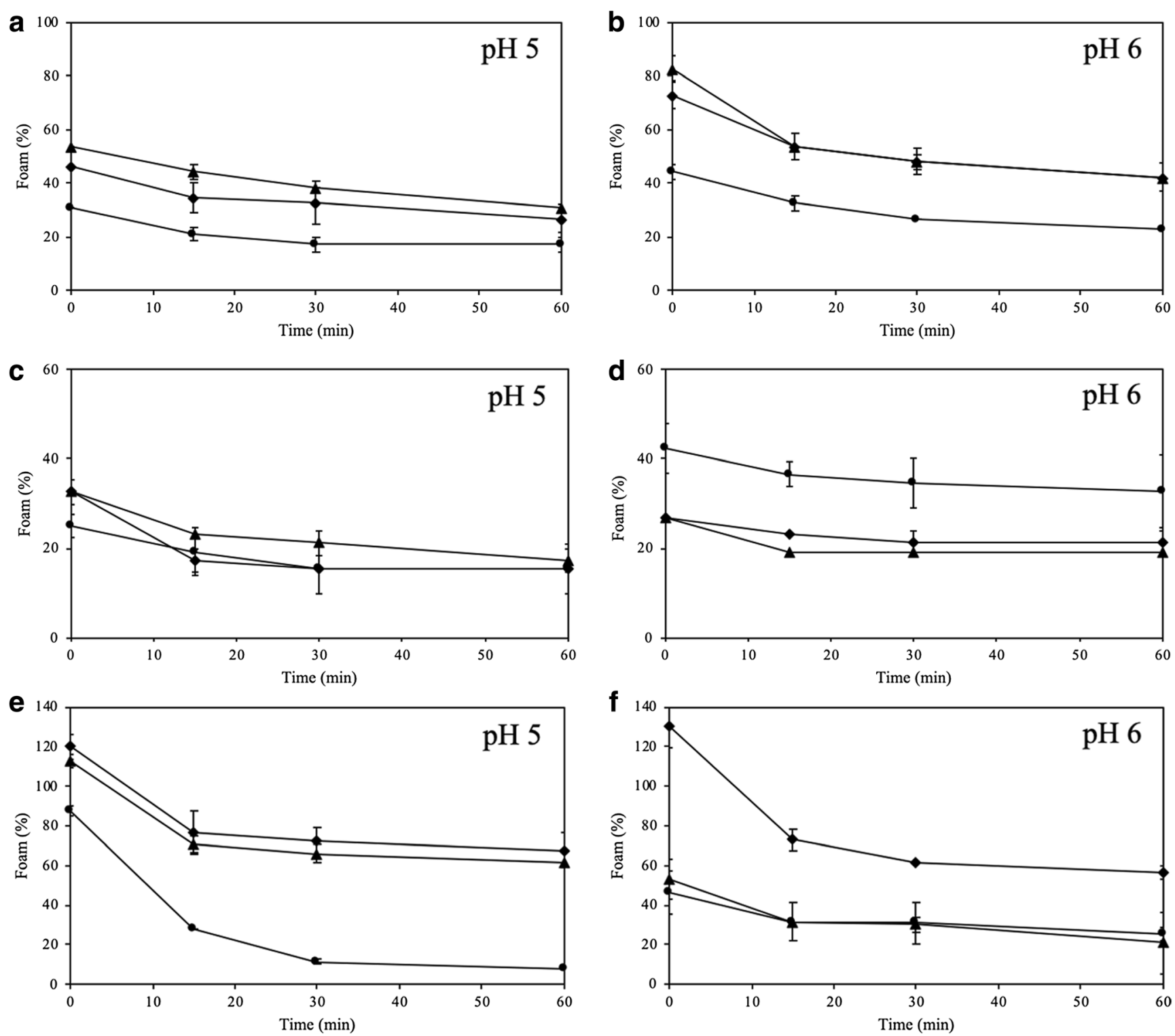

Fig. 3 Foam capacity and stability of pea $(\mathbf{a}, \mathbf{b})$, rice $(\mathbf{c}, \mathbf{d})$ and gluten $(\mathbf{e}, \mathbf{f})$ concentrates at pH 5 and 6 treated at $0(\bullet), 20,000(\bullet)$ and $60,000(\mathbf{\Delta})$ pulses
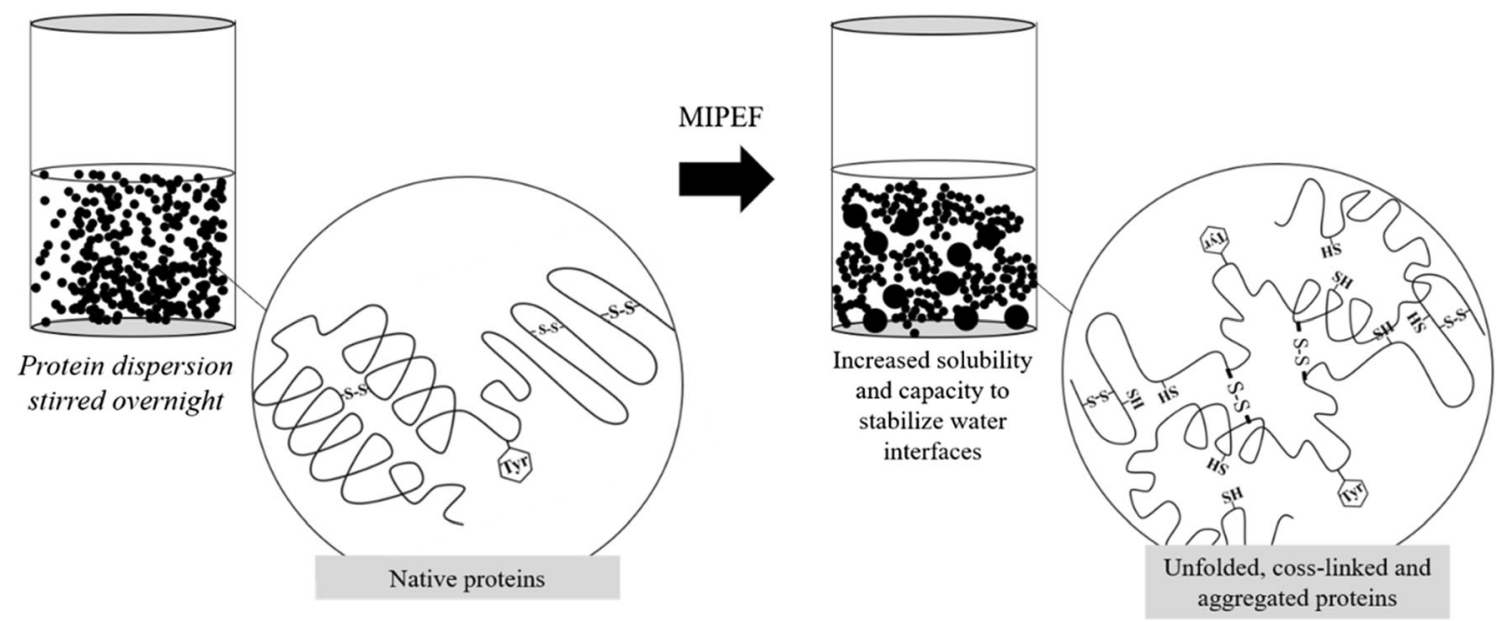

Fig. 4 Schematic representation of the structural changes induced by MIPEF in gluten at $\mathrm{pH}$ 5, taken as an example of a protein sensitive to electric fields. 
6 exposed to 20,000 pulses showing the best performance. Figure 4 shows a schematic representation of the different mechanisms at the basis of MIPEF-induced modifications in the structure of gluten at $\mathrm{pH}$ 5. The latter was chosen as a possible example of proteins sensitive to electric fields. The treatment might cause the cleavage of disulphide bonds, resulting in exposure of SH groups as well as in loss of $\alpha$ helix and $\beta$-sheet structures with concomitant increase in random coil ones. This is in agreement with literature showing a decrease in the ordered structures ( $\alpha$-helices) and an increase in disorder random coils with a concomitant exposure of surface free sulfhydryls (Guan et al. 2010; Liu et al. 2013).

The complex interplay among these different effects might be responsible for an increase in protein solubility and capacity of interacting at the water/air interphase, resulting in higher foaming ability.

\section{Conclusions}

In this study, the effects of MIPEF on structural and functional properties of vegetable protein concentrates were evaluated for the first time. Results indicate that the impact of MIPEF is particularly complex since affected by multiple factors concurring to steer protein energy landscape and potential interactions among particles and with solvents. MIPEF might induce structural rearrangement only on those proteins that are sensitive to electric fields. This is the case of gluten rich in highly reactive sulfhydryl groups, where the disulphide interchange could have a great impact in terms of solubility, foaming capacity and water and oil holding capacity. By contrast, rice and pea proteins, poorer in sulfhydryl groups, might suffer negligible functional changes upon MIPEF treatment. Moreover, other environmental and technological parameters, such as $\mathrm{pH}$, concentration and PEF conditions, could exert a critical role in determining protein conformation and relevant functional properties.

For this reason, in the current state, it is not possible to make generalizations about MIPEF-induced effects on plant proteins. Further research is required to understand MIPEF sensitivity of each protein of interest as well as the potential effects of MIPEF on protein nutritional functionality and the PEF modified proteins behaviour in the human body.

Authors' Contributions (CASRAI CRediT) S. M.: formal analysis, investigation, visualization, writing - original draft, writing - review and editing; S. C.: conceptualization, resources, supervision, writing - review and editing; G. B.: investigation; L. M.: conceptualization, resources, supervision, writing - original draft, writing - review and editing.

Funding Open access funding provided by Università degli Studi di Udine within the CRUI-CARE Agreement.

Availability of Data and Material Not applicable.

\section{Compliance with Ethical Standards}

Conflict of Interest The authors declare that they have no conflict of interest.

Ethics Approval Not applicable.

Consent to Participate Not applicable.

Consent for Publication Not applicable.

Code Availability Not applicable.

Open Access This article is licensed under a Creative Commons Attribution 4.0 International License, which permits use, sharing, adaptation, distribution and reproduction in any medium or format, as long as you give appropriate credit to the original author(s) and the source, provide a link to the Creative Commons licence, and indicate if changes were made. The images or other third party material in this article are included in the article's Creative Commons licence, unless indicated otherwise in a credit line to the material. If material is not included in the article's Creative Commons licence and your intended use is not permitted by statutory regulation or exceeds the permitted use, you will need to obtain permission directly from the copyright holder. To view a copy of this licence, visit http://creativecommons.org/licenses/by/4.0/.

\section{References}

Aluko, R. E., Mofolasayo, O. A., \& Watts, B. M. (2009). Emulsifying and foaming properties of commercial yellow pea (Pisum sativum L.) seed flours. Journal of Agricultural and Food Chemistry, 57(20), 9793-9800.

Ami, D., Mereghetti, P., \& Maria, S. (2013). Multivariate analysis for Fourier transform infrared spectra of complex biological systems and processes. In L. V. Freitas \& A. P. B. R. de Freitas (Eds.), Multivariate Analysis in Management, Engineering and the Sciences (pp. 189-220). London: InTech.

Barba, F. J., Parniakov, O., Pereira, S. A., Wiktor, A., Grimi, N., Boussetta, N., Saraiva, J. A., Raso, J., Martin-Belloso, O., Witrowa-Rajchert, D., Lebovka, N., \& Vorobiev, E. (2015). Current applications and new opportunities for the use of pulsed electric fields in food science and industry. Food Research International, 77, 773-798.

Barsotti, L., Dumay, E., Mu, T. H., Fernandez Diaz, M. D., \& Cheftel, J. C. (2001). Effects of high voltage electric pulses on protein-based food constituents and structures. Trends in Food Science and Technology, 12(3-4), 136-144.

Boland, M. J., Rae, A. N., Vereijken, J. M., Meuwissen, M. P. M., Fischer, A. R. H., van Boekel, M. A. J. S., Rutherfurd, S. M., Gruppen, H., Moughan, P. J., \& Hendriks, W. H. (2013). The future supply of animal-derived protein for human consumption. Trends in Food Science and Technology, 29(1), 62-73.

Boye, J., Zare, F., \& Pletch, A. (2010). Pulse proteins: Processing, characterization, functional properties and applications in food and feed. Food Research International, 43(2), 414-431.

Cao, X., Wen, H., Li, C., \& Gu, Z. (2009). Differences in functional properties and biochemical characteristics of congenetic rice proteins. Journal of Cereal Science, 50(2), 184-189.

Carbonaro, M., Maselli, P., Dore, P., \& Nucara, A. (2008). Application of Fourier transform infrared spectroscopy to legume seed flour analysis. Food Chemistry, 108(1), 361-368. 
Carbonaro, M., Maselli, P., \& Nucara, A. (2012). Relationship between digestibility and secondary structure of raw and thermally treated legume proteins: A Fourier transform infrared (FT-IR) spectroscopic study. Amino Acids, 43(2), 911-921.

Day, L., Augustin, M. A., Batey, I. L., \& Wrigley, C. W. (2006). Wheatgluten uses and industry needs. Trends in Food Science and Technology, 17(2), 82-90.

Dong, M., Xu, Y., Zhang, Y., Han, M., Wang, P., Xu, X., \& Zhou, G. (2020). Physicochemical and structural properties of myofibrillar proteins isolated from pale, soft, exudative (PSE)-like chicken breast meat: Effects of pulsed electric field (PEF). Innovative Food Science and Emerging Technologies, 59, 102277.

Donsì, F., Ferrari, G., \& Pataro, G. (2010). Applications of pulsed electric field treatments for the enhancement of mass transfer from vegetable tissue. Food Engineering Reviews, 2(2), 109-130.

Esteghlal, S., Gahruie, H. H., Niakousari, M., Barba, F. J., Bekhit, A. E. D., Mallikarjunan, K., \& Roohinejad, S. (2019). Bridging the knowledge gap for the impact of non-thermal processing on proteins and amino acids. Foods, 8, 1-22.

FAO. (2013). The State of Food Insecurity in the World.

FAO. (2017). The future of food and agriculture-Trends and challenges.

Fasolin, L. H., Pereira, R. N., Pinheiro, A. C., Martins, J. T., Andrade, C. C. P., Ramos, O. L., \& Vicente, A. A. (2019). Emergent food proteins - Towards sustainability, health and innovation. Food Research International, 125, 108586.

Fernandez-Diaz, M. D., Barsotti, L., Dumay, E., \& Cheftel, J. C. (2000). Effects of pulsed electric fields on ovalbumin solutions and dialyzed egg white. Journal of Agricultural and Food Chemistry, 48(6), 2332-2339.

Georget, D. M. R., \& Belton, P. S. (2006). Effects of temperature and water content on the secondary structure of wheat gluten studied by FTIR spectroscopy. Biomacromolecules, 7(2), 469-475.

Giteru, S. G., Oey, I., \& Ali, M. A. (2018). Feasibility of using pulsed electric fields to modify biomacromolecules: A review. Trends in Food Science and Technology, 72, 91-113.

Giteru, S. G., Cridge, B., Oey, I., Ali, A., \& Altermann, E. (2020). In-vitro degradation and toxicological assessment of pulsed electric fields crosslinked zein-chitosan-poly (vinyl alcohol) biopolymeric films. Food and Chemical Toxicology, 135, 111048.

Goldfarb, A. R., Saidel, L. J., \& Mosovich, E. (1951). The ultraviolet absorption spectra of proteins. The Journal of biological chemistry, 193(1), 397-404.

Grimi, N., Dubois, A., Marchal, L., Jubeau, S., Lebovka, N. I., \& Vorobiev, E. (2014). Selective extraction from microalgae Nannochloropsis sp. using different methods of cell disruption. Bioresource Technology, 153, 254-259.

Guan, Y. G., Lin, H., Han, Z., Wang, J., Yu, S. J., Zeng, X. A., Liu, Y. Y., $\mathrm{Xu}, \mathrm{C} . \mathrm{H} .$, \& Sun, W. W. (2010). Effects of pulsed electric field treatment on a bovine serum albumin-dextran model system, a means of promoting the Maillard reaction. Food Chemistry, 123(2), 275-280.

Knorr, D., Froehling, A., Jaeger, H., Reineke, K., Schlueter, O., \& Schoessler, K. (2011). Emerging technologies in food processing. Annual review of food science and technology, 2(1), 203-235.

Laemmli, U. K. (1970). Cleavage of structural proteins during the assembly of the head of bacteriophage T4. Nature, 227(5259), 680-685.

Li, Y., Chen, Z., \& Mo, H. (2007). Effects of pulsed electric fields on physicochemical properties of soybean protein isolates. $L W T$ - Food Science and Technology, 40(7), 1167-1175.

Liu, Y. Y., Zeng, X. A., \& Chen, X. D. (2010). Effects of pulsed electric fields and heat treatments on SPI structure analyzed by FTIR. Spectroscopy and Spectral Analysis, 30(9), 2340-2344.

Liu, Y. Y., Zeng, X. A., Deng, Z., Yu, S. J., \& Yamasaki, S. (2011). Effect of pulsed electric field on the secondary structure and thermal properties of soy protein isolate. European Food Research and Technology, 233(5), 841-850.
Liu, Y. Y., Zhang, Y., Zeng, X. A., El-Mashad, H., Pan, Z. L., \& Wang, Q. J. (2013). Effect of pulsed electric field on microstructure of some amino acid group of soy protein isolates. International Journal of Food Engineering, 10, 113-120.

Lu, Z. X., He, J. F., Zhang, Y. C., \& Bing, D. J. (2019). Composition, physicochemical properties of pea protein and its application in functional foods. Critical Reviews in Food Science and Nutrition, 60, 2593-2605.

Luo, W., Zhang, R. B., Wang, L. M., Chen, J., \& Guan, Z. C. (2010). Conformation changes of polyphenol oxidase and lipoxygenase induced by PEF treatment. Journal of Applied Electrochemistry, 40(2), 295-301.

Majzoobi, M., \& Abedi, E. (2014). Effects of pH changes on functional properties of native and acetylated wheat gluten. International Food Research Journal, 21, 1219-1224.

Nadeem, M., Anjum, F. M., Khan, M. R., Sajjad, M., Hussain, S., \& Arshad, M. S. (2016). Electrophoretic characteristics of gluten proteins as influenced by crop year and variety. International Journal of Food Properties, 19(4), 897-910.

Ohshima, T., Tamura, T., \& Sato, M. (2007). Influence of pulsed electric field on various enzyme activities. Journal of Electrostatics, 65(3), 156-161.

Osen, R., Toelstede, S., Wild, F., Eisner, P., \& Schweiggert-Weisz, U. (2014). High moisture extrusion cooking of pea protein isolates: Raw material characteristics, extruder responses, and texture properties. Journal of Food Engineering, 127, 67-74.

Panozzo, A., Manzocco, L., Calligaris, S., Bartolomeoli, I., Maifreni, M., Lippe, G., \& Nicoli, M. C. (2014). Effect of high pressure homogenisation on microbial inactivation, protein structure and functionality of egg white. Food Research International, 62, 718-725.

Papargyropoulou, E., Lozano, R. K., Steinberger, J., Wright, N., \& Ujang, Z. B. (2014). The food waste hierarchy as a framework for the management of food surplus and food waste. Journal of Cleaner Production, 76, 106-115.

Pataro, G., Bobinaite, R., Bobinas, Č., Šatkauskas, S., Raudonis, R., Visockis, M., Ferrari, G., \& Viškelis, P. (2017). Improving the extraction of juice and anthocyanins from blueberry fruits and their byproducts by application of pulsed electric fields. Food and Bioprocess Technology, 10(9), 1595-1605.

Picart-Palmade, L., Cunault, C., Chevalier-Lucia, D., Belleville, M. P., \& Marchesseau, S. (2019). Potentialities and limits of some nonthermal technologies to improve sustainability of food processing. Frontiers in Nutrition, 5(130), 1-18.

Pojić, M., Mišan, A., \& Tiwari, B. (2018). Eco-innovative technologies for extraction of proteins for human consumption from renewable protein sources of plant origin. Trends in Food Science and Technology, 75, 93-104.

Preece, K. E., Hooshyar, N., Krijgsman, A. J., Fryer, P. J., \& Zuidam, N. J. (2017). Intensification of protein extraction from soybean processing materials using hydrodynamic cavitation. Innovative Food Science and Emerging Technologies, 41, 47-55.

Puértolas, E., Luengo, E., Álvarez, I., \& Raso, J. (2012). Improving mass transfer to soften tissues by pulsed electric fields: Fundamentals and applications. Annual Review of Food Science and Technology, 3(1), 263-282.

Qian, J. Y., Ma, L. J., Wang, L. J., \& Jiang, W. (2016). Effect of pulsed electric field on structural properties of protein in solid state. $L W T$ Food Science and Technology, 74, 331-337.

Ran, X. L., Zhang, M., Wang, Y., \& Adhikari, B. (2019). Novel technologies applied for recovery and value addition of high value compounds from plant byproducts: A review. Critical Reviews in Food Science and Nutrition, 59, 450-461.

Shand, P. J., Ya, H., Pietrasik, Z., \& Wanasundara, P. K. J. P. D. (2007). Physicochemical and textural properties of heat-induced pea protein isolate gels. Food Chemistry, 102(4), 1119-1130. 
Shevkani, K., Singh, N., Kaur, A., \& Rana, J. C. (2015). Structural and functional characterization of kidney bean and field pea protein isolates: A comparative study. Food Hydrocolloids, 43, 679-689.

Soliva-Fortuny, R., Balasa, A., Knorr, D., \& Martín-Belloso, O. (2009). Effects of pulsed electric fields on bioactive compounds in foods: a review. Trends in Food Science and Technology., 20(11-12), 544 556.

Song, M., Fung, T. T., Hu, F. B., Willett, W. C., Longo, V. D., Chan, A. T., \& Giovannucci, E. L. (2016). Association of animal and plant protein intake with all-cause and cause-specific mortality. JAMA Internal Medicine, 176(10), 1453-1463.

Sow, L. C., \& Yang, H. (2015). Effects of salt and sugar addition on the physicochemical properties and nanostructure of fish gelatin. Food Hydrocolloids, 45, 72-82.

Sow, L. C., Peh, Y. R., Pekerti, B. N., Fu, C., Bansal, N., \& Yang, H. (2017). Nanostructural analysis and textural modification of tilapia fish gelatin affected by gellan and calcium chloride addition. $L W T$ Food Science and Technology, 85, 137-145.

Tharrey, M., Mariotti, F., Mashchak, A., Barbillon, P., Delattre, M., \& Fraser, G. E. (2018). Patterns of plant and animal protein intake are strongly associated with cardiovascular mortality: The Adventist Health Study-2 cohort. International Journal of Epidemiology, 47(5), 1603-1612.

Timmermans, R. A. H., Mastwijk, H. C., Berendsen, L. B. J. M., Nederhoff, A. L., Matser, A. M., Van Boekel, M. A. J. S., \& Nierop Groot, M. N. (2019). Moderate intensity Pulsed Electric Fields (PEF) as alternative mild preservation technology for fruit juice. International Journal of Food Microbiology, 298, 63-73.

Toepfl, S., Heinz, V., \& Knorr, D. (2006). Applications of pulsed electric fields technology for the food industry. In J. Raso \& V. Heinz (Eds.), Pulsed Electric Fields Technology for the Food Industry (pp. 197222). New York: Springer.

van der Spiegel, M., Noordam, M. Y. Y., \& van der Fels-Klerx, H. J. J. (2013). Safety of novel protein sources (insects, microalgae, seaweed, duckweed, and rapeseed) and legislative aspects for their application in food and feed production. Comprehensive Reviews in Food Science and Food Safety, 12(6), 662-678.

Wang, T., Wang, L., Wang, R., \& Chen, Z. (2016). Effects of freezemilling on the physicochemical properties of rice protein isolates. LWT - Food Science and Technology, 65, 832-839.

Wei, Z., Ruijin, Y., Yali, T., Wenbin, Z., \& Xiao, H. (2009). Investigation of the protein-protein aggregation of egg white proteins under pulsed electric fields. Journal of Agricultural and Food Chemistry, 57, 3571-3577.

Wu, L., Zhao, W., Yang, R., \& Chen, X. (2014). Effects of pulsed electric fields processing on stability of egg white proteins. Journal of Food Engineering, 139, 13-18.
Wu, L., Zhao, W., Yang, R., Yan, W., \& Sun, Q. (2016). Aggregation of egg white proteins with pulsed electric fields and thermal processes. Journal of the science of food and agriculture, 96(10), 3334-3341.

Xiang, B. Y., Ngadi, M. O., Ochoa-Martinez, L. A., \& Simpson, M. V. (2011a). Pulsed electric field-induced structural modification of whey protein isolate. Food and Bioprocess Technology, 4(8), $1341-1348$.

Xiang, B. Y., Simpson, M. V., Ngadi, M. O., \& Simpson, B. K. (2011b). Effect of pulsed electric field on the rheological and colour properties of soy milk. International Journal of Food Sciences and Nutrition, 62(8), 787-793.

Yeom, H. W., Zhang, Q. H., \& Dunne, C. P. (1999). Inactivation of papain by pulsed electric fields in a continuous system. Food Chemistry, 67(1), 53-59.

Yu, X., Bals, O., Grimi, N., \& Vorobiev, E. (2015). A new way for the oil plant biomass valorization: Polyphenols and proteins extraction from rapeseed stems and leaves assisted by pulsed electric fields. Industrial Crops and Products, 74, 309-318.

Zhang, L., Wang, L. J., Jiang, W., \& Qian, J. Y. (2017). Effect of pulsed electric field on functional and structural properties of canola protein by pretreating seeds to elevate oil yield. LWT - Food Science and Technology, 84, 73-81.

Zhao, W., \& Yang, R. (2008). Comparative study of inactivation and conformational change of lysozyme induced by pulsed electric fields and heat. European Food Research and Technology, 228(1), $47-54$.

Zhao, W., \& Yang, R. (2009). Effect of high-intensity pulsed electric fields on the activity, conformation and self-aggregation of pepsin. Food Chemistry, 114(3), 777-781.

Zhao, W., \& Yang, R. (2010). Experimental study on conformational changes of lysozyme in solution induced by pulsed electric field and thermal stresses. Journal of Physical Chemistry B, 114(1), 503-510.

Zhao, W., \& Yang, R. (2012). Pulsed electric field induced aggregation of food proteins: Ovalbumin and bovine serum albumin. Food and Bioprocess Technology, 5(5), 1706-1714.

Zhao, W., Yang, R., \& Zhang, H. Q. (2012). Recent advances in the action of pulsed electric fields on enzymes and food component proteins. Trends in Food Science and Technology, 27(2), 83-96.

Zhao, W., Tang, Y., Lu, L., Chen, X., \& Li, C. (2014). Review: Pulsed Electric Fields Processing of Protein-Based Foods. Food and Bioprocess Technology, 7(1), 114-125.

Zhong, K., Wu, J., Wang, Z., Chen, F., Liao, X., Hu, X., \& Zhang, Z. (2007). Inactivation kinetics and secondary structural change of PEF-treated POD and PPO. Food Chemistry, 100(1), 115-123.

Publisher's Note Springer Nature remains neutral with regard to jurisdictional claims in published maps and institutional affiliations. 